\title{
The Preliminary Study for Development of Phoneme Perception Test Tool in the School-Aged Children
}

\author{
Eun-Yeong Shin ${ }^{1,2}$, Hyoln Lee ${ }^{3}$, Soo Jin Cho ${ }^{4}$ \\ ${ }^{1}$ SEY Hearing Rehabilitation Center, Suncheon, Korea \\ ${ }^{2}$ Department of Speech-Language Pathology and Audiology, Sehan University, Yeongam, Korea \\ ${ }^{3}$ The Faculty of Liberal Arts, Sehan University, Dangjin, Korea \\ ${ }^{4}$ Department of Speech-Language Pathology, Nambu University, Gwangju, Korea
}

Received: September 23, 2020 Revised: October 13, 2020

Accepted: October 18, 2020

Correspondence:

Soo Jin Cho, PhD

Department of Speech-

Language Pathology,

Nambu University,

1 Nambudae-gil, Gwangsan-gu,

Gwangju 62271, Korea

Tel: +82-62-970-0215

Fax: +82-62-970-0118

E-mail: sj2434@nambu.ac.kr

\begin{abstract}
Purpose: The purpose of this study is to develop a test list for school-aged children that can evaluate consonant perception ability and verify the validity and difficulty. Methods: The test list consisted of 127 initial and 94 final consonant test items with meaningful one-syllable words and was developed in two types for each difficulty level. To verify the validity of the developed phoneme perception test tool, twenty children with normal hearing were tested for the validity of the results, and the contents were verified by experts in various fields. Results: As a result of comparing the rate of correct response according to the type of test item (initial vs. final consonant) and difficulty (easy vs. difficult item), the initial and easy responses were higher than the final and hard item, respectively, so the difficulty level of the test list was appropriate. In addition, there was no statistical difference in the rate of correct answers according to the test speakers, and the content validity analysis for experts verified that the developed test list was appropriate as a phoneme perception test tool for school-age children. Conclusion: The initial and final consonant test items developed through this study consisted of one target word and three examples which are a pair of minimum confrontations with the target word and are heteromorphic test lists consisting of easy and hard types according to the difficulty of the example. It could also be useful for not only the evaluation of the consonant perception ability but also rehabilitation.
\end{abstract}

Key Words: Aural rehabilitation, Closed set, Phoneme perception test, School-aged children, Speech perception.

\section{INTRODUCTION}

소리 자극이 말초청각기관을 거쳐 청각피질 영역에서는 대뇌 의 다른 영역에서 일어나는 활동들과 연합하여 다양한 형태의 정보처리과정을 거치게 되는데, 이러한 현상을 청지각(auditory perception)이라고 하고(The Korean Audiological Society, 2015), 청지각 능력 중 의미 있는 말소리에 대한 지각을 말지각 (speech perception)이라고 한다. 말지각 능력은 청각 수행력과 밀접하게 연관되어 있어서 청각 수행력 범위 내에서 이해할 수 있으며, 위계적인 발달 단계를 따르고 있기 때문에 말지각 단계 에 근거하여 청능 및 말지각 평가 도구나 청능재활 프로그램을 개발하고 적용하는 것이 바람직하다(Archbold et al., 1995; Er-

(c) This is an Open Access article distributed under the terms of the Creative Commons Attribution Non-Commercial License (https://creativecommons.org/licenses/by-nc/4.0) which permits unrestricted non-commercial use, distribution, and reproduction in any medium, provided the original work is properly cited. ber, 1982; Geers et al., 2000). 또한 말지각 단계는 서로 중첩되 거나 관련을 맺고 있고 또한 빠른 속도로 단계가 진행되기도 하여 각 요소들이 분리되어 있다고 보기 어렵지만, 난청인의 말 지각 단계의 문제나 어려움을 파악하고 청능재활에 도움을 위 해서는 각 단계별로 평가를 진행하여 적합한 청능재활을 하는 것이 필요하다(The Korean Audiological Society, 2015).

말지각검사는 난청인에게 낱말이나 문장을 들려주고 그림이 나 사물을 지적하거나 따라 말하도록 하여 말소리의 음향학적 특성을 얼마나 정확하게 듣고 이해하는지를 평가할 수 있다. 또 한 보청기와 인공와우와 같은 청각보조기기의 효과와 적합의 적절성을 평가하고, 청능재활의 목표를 설정하거나 청능재활 도구로서도 유용하게 사용할 수 있다(Bahng et al., 2005; Kim et al., 2004; Kirk et al., 1995). 특히 듣기와 구어 이해 능력은 '말'로 표현하는 의사소통의 발전에 가장 기본이 되므로, 난청 인의 일상생활 속 의사소통 능력의 정도를 정량화하기 위한 수 
행력 평가에서는 타당도와 신뢰도가 입증된 표준화된 말지각 검사 도구를 사용해야 한다. 이러한 표준화된 검사 도구는 보 다 객관적인 정보를 제공하여 여러 전문가들 간의 협조를 원활 하게 하고 장기간의 청능재활과 언어재활에 따른 정기적인 평가 결과를 비교할 수 있기 때문에 유용하다(Katz et al., 2009; Lee et al., 2009).

난청인의 말지각 단계의 문제나 어려움을 파악하고 청능재 활과 언어재활에 도움을 주기 위해서는 말지각 단계별로 말소 리의 단위(음소, 단어, 구, 문장 등)에 따라 평가를 하는 것이 중 요하다. 그 중 음소 중심의 평가는 음소 및 음절 단위에서 모음 과 자음의 인지 능력을 평가하는 것으로 대상자의 언어 능력과 관련 없이 말지각 능력을 객관적으로 평가하는 데 적합하며, 상 향식(bottom-up) 방법의 청능재활을 시행할 경우 재활을 위한 목표 음소 설정이나 재활 도구로 유용하게 사용할 수 있다. 난 청인의 경우 말소리의 고저, 억양, 장단 등의 초분절적인 요소 보다 자음이나 모음과 같은 분절적 요소의 말소리 지각에 어려 움을 보이고, 분절적 요소 중 $1,000 \mathrm{~Hz}$ 이상의 비교적 고주파수 에 분포하고 있는 마찰음이나 파찰음과 같은 자음에 대한 지각 을 더 어려워할 수 있으므로 음소 중심의 평가 중 자음지각에 대한 평가는 그 유용성이 크다(Archbold et al., 1995; Erber, 1982; Geers et al., 2000; Katz et al., 2009; Northern \& Downs, 2002; Tye-Murray, 2015).

외국의 경우 영어권에서 분절음 중 자음지각 능력을 평가할 수 있는 표준화된 도구가 이미 개발되었는데, Modified Rhyme Test (MRT) (House et al., 1965)와 California Consonant Test (CCT) (Owens \& Schubert, 1977) 검사가 대표적이다. 이 두 가 지 모두 유의미 일 음절 단어의 보기가 제시되는 폐쇄형(closedset) 검사로 자음의 위치에 따라 특정 음소의 지각 능력을 평가 할 수 있다. 구체적으로 MRT는 50개 일 음절 단어로 된 6개 목록의 총 300 개 단어(자음 + 모음 + 자음, 자음 + 모음, 모음 + 자음)로 구성되어 있으며, 하나의 목표어와 모음을 중심으로 초성과 종성에서 변화를 준 5 개의 최소대립쌍인 보기어로 된 6지선다형(예시: bent, went, sent, tent, dent, rent) 검사이다. $\mathrm{CCT}$ 검사는 총 100 개의 일 음절 단어(자음 + 모음 + 자음)로 구성되어 있으며, 하나의 목표어당 3개의 최소대립어로 된 4지선 다형이다. 이 외에도 MRT 평가 도구를 변형한 Rhyming Minimal Contrasts Test (Griffiths, 1967)가 있고, CCT 평가 도구를 기반으로 모음의 인식까지 측정할 수 있는 A New Minimal Contrasts Closed-Response-Set Speech Test (Pederson \& Studebaker, 1972)가 있다.

국내에서도 다양한 일 음절 평가 도구들이 음소지각검사 도 구로 사용되는데, 한국표준 학령기용 단음절어표(Korean Standard Monosyllabic Word List) (Kim et al., 2008), 국립특
수교육원 말지각발달검사(Korean National Institute for Special Education-Developmental Assessment of Speech Perception) (Song et al., 2010)의 하위검사인 자모음검사, Evaluation of Auditory Response to Speech (EARS) (Allum et al., 1996)의 한국어 버전인 EARS-K (Park et al, 2004)의 단음절 검사, 학령 전 아동의 단음절 말지각검사(Lee et al., 2009) 등이 있다. 그 외 영어권의 RT나 CCT 검사와 같이 위치별 특정 자 음에 대한 지각 능력을 평가할 수 있는 성인용 자음지각검사 (Korean Consonant Perception Test, KCPT)(Kim et al., 2011) 가 개발되어 있다.

최근 들어 보청기나 인공와우와 같은 청각보조기기의 기술 적 진보로 난청 아동의 정상적인 말·언어에 대한 습득 가능성 이 더욱 증가함에 따라서 청능재활의 중요성과 요구가 높아지 고 있다. 특히 학령기 난청 아동들의 경우 효과적인 구어 의사 소통과 통합교육 환경에서 학습력 향상을 위해서는 정확한 말 지각 능력에 대한 평가 및 재활이 절실히 요구된다. 말지각 능 력은 생활 연령과 직접적인 연관이 있기 때문에 난청 아동의 말지각을 정확하게 평가하기 위해서는 연령별로 세분화된 검사 도구가 필요하지만(Wang et al., 2008), 현재 임상에서는 학령 기 난청 아동의 자음에 대한 말지각을 평가를 할 때 필요에 따 라 비공식적인 평가 도구를 통해 음소의 말지각을 위한 단어의 조건을 갖추지 않은 채 단지 몇 개의 자음이 포함된 단어 목록 을 사용하거나, 기존 개발된 학령기용 일 음절 단어를 사용하 여 검사하는 실정이다. 또한 개발되어 있는 대부분의 일 음절 단어 평가 목록은 음소 수준의 평가보다는 단어 수준의 평가 로 단어 인지 능력을 측정하기 위한 도구로 사용할 수 있으므 로 음소 수준을 평가하기에는 제한점이 있다. 기존에 개발된 음소 수준의 말지각 평가도 단어의 목록 수가 적어 평가를 통 한 기억효과 혹은 학습효과가 있을 수 있거나, 특정 음소를 듣 지 못하는 규칙성을 알기 위한 평가로 사용하기에는 적합하지 않는 점이 있으며, $\mathrm{KCPT}$ 검사의 경우 목표어가 노인을 대상으 로 개발되어 있어 학령기 난청 아동을 대상으로 평가를 할 때 는 한계점이 있다.

이에 본 연구는 학령기용 음소지각검사 도구 개발 및 보급을 위한 기초 단계로 음소지각 능력을 평가할 수 있는 검사 목록 을 제작하여 비장애 아동을 대상으로 타당도와 신뢰도를 검증 하여 추후 난청 아동의 음소지각 능력을 정확히 평가할 수 있 는 표준화된 학령기용 음소지각평가 도구 개발을 위한 기초 자 료로 활용하고자 한다. 


\section{MATERIALS AND METHODS}

\section{Development of phoneme perception test lists for school-aged children}

학령기용 음소지각검사 도구를 통해 평가하고자 하는 음소 는 중성 모음을 제외한 초성과 종성의 자음으로 초성과 종성검 사용 문항을 개발하였다. 검사 문항은 4지선다형의 폐쇄형으로 목표어와 보기어로 구성하였다. 목표어와 보기어의 형태는 초 성검사 문항의 경우 초성을 다르게 하고 중성과 종성은 동일한 최소대립쌍으로(예: 문, 눈, 운, 푼), 종성검사 문항의 경우는 종 성을 다르게 하고 초성과 중성은 동일한 최소대립쌍으로 구성 한 일 음절 단어(예: 군, 국, 굽, 구)이다. 단어 선정 기준은 우선 발음규칙(Lee, 2014), 친숙도(Kim, 2003), 회화체 음소 빈도수 (Shin et al., 2019)를 고려한 유의미 일 음절어로 결정하고, 동 일 목표어에 따라 발음규칙과 친숙도를 고려한 보기어를 선정 하였다. 보기어의 난이도를 달리한 이형목록을 개발하기 위하 여 조음 방법과 조음 위치(Kwon et al., 2011)에 따라 보기어의 난이도를 조절한 검사 목록으로 쉬운형(easy type)과 어려운형 (hard type)으로 각각 제작하였다.

검사 문항의 개발 과정을 전체적으로 살펴보면, 목표어를 먼 저 선정하고 목표어에 따른 보기어를 배치하여 목록을 구성하 였다. 특히 목표어의 경우, 일 차로 조합 가능한 일 음절 중 유 의미 일 음절 827 개를 추출한 뒤, 친숙도와 음소 출현율을 고 려하여 초성·중성·종성, 중성·종성, 초성·중성의 유의미 일 음절로 구성된 목표어 초성검사 문항 127 개, 종성검사 문항 94 개를 쉬운형과 어려운형으로 각각 제작하였다. 제작된 목표어 의 구성은 초성·중성·종성, 중성·종성, 초성·중성의 유의미 일 음절의 형태로 구체적인 과정은 다음과 같다.

\section{Selection of target words}

목표어를 효과적으로 선정하기 위하여 먼저 발음 규칙을 통 한 한국어의 조합 가능한 유의미 일 음절 단어를 파악한 후 친 숙도를 고려하였고, 그 후 음소지각검사 도구의 단어가 아동의 일상 회화음과 동일한 음성학적 분포를 갖출 수 있도록 하였다.

Meaningful monosyllabic words sampling

우리나라 말에서 자음과 모음의 모든 가능한 조합을 고려하 였고, 그 중 유의미 일 음절 단어를 조사하였다. 초성자음은 평 음, 격음, 경음 총 19 개, 모음은 단모음과 이중모음으로 21 개, 종 성자음은 28개로 사용할 수 있다. 종성 위치에 있는 자음은 실 제로 발음이 될 때에는 7종성(/ᄀ/, /ㄴ/, /ㄷ/, /ㄹ/, /ㅁ/, /ㅂ/, /O/) 으로 발음이 된다. 이는 음절말의 파열음(폐쇄음), 마찰음, 파찰 음은 자음의 조음 방법이 변하지만, 같은 조음 위치의 평폐쇄
음인 / ᄀ//, /ㄷ/, /ㅂ/ 중의 하나로 발음이 되는 음절말 평파열음 (폐쇄음)화 때문이다(Lee, 2014). 그 외 종성이 없는 일 음절어 를 포함할 때 일 음절 단어는 총 $19 \times 21 \times 8=3,192$ 개로 조 사되었다. 조합한 일 음절 단어 중 모음의 발음과 관련한 표준 발음법과 국립 국어원 표준국어대사전을 이용하여 사전에 있 는 827 개의 유의미 일 음절 단어를 추출하였다.

\section{Considering familiarity}

추출한 유의미 일 음절 단어 중 외국인들이 한국어를 학습 할 때 빈도수가 높은 어휘 목록으로 참고하는 한국어 학습용 어휘 목록(National Institute of the Korean Language, 2003) 의 1단계 어휘와 국어에서 실제로 사용하는 어휘의 목록을 빈 도수에 따라 등급화한 등급별 국어교육용 어휘(Kim, 2003)의 1,2 등급 단어를 선택하였다.

\section{Considering phoneme frequency}

우리나라 회화체의 음소 빈도와 학령기 아동의 초성자음, 모 음, 종성자음의 출현율과 유사한 음소적 균형과 분포를 고려한 목표어를 선정하였다(Kim et al., 2008; Shin et al., 2019). 특히 모든 음소의 분포를 완전히 일치시킬 수는 없으므로 초성검사 문항은 초성자음과 모음의 분포를, 종성검사 문항은 모음과 종 성자음의 분포를 중심으로 고려하였다. 또한 음소 출현 빈도를 아동의 일상생활 대화와 유사하게 하기 위하여 초성의 자음이 없는 / $0 /$ 을 포함하였고, 종성이 없는 무종성의 일 음절 단어도 포함시켰다. 다만, 초등학교 저학년의 이용을 생각하여 겹받침 일 음절 단어는 배제하였다. 초성검사와 종성검사를 동시에 시 행할 것을 고려하여 초성검사 문항의 목표어와 종성검사 문항 의 목표어를 되도록 겹치지 않도록 선정하였고, 쉬운형과 어려 운형의 목표어는 동일하게 선정해서 초성·중성·종성, 중성·종 성, 초성·중성의 유의미 일 음절로 구성하였다.

제작한 검사 문항의 음소 출현율을 분석한 결과, 초성검사 문항 의 초성의 경우 $/ 0 /$ 음소의 비율이 가장 높았고, 그 다음이 $/ 7 /$, /ㄹ/, /ㄴ/ 순으로 나타나 Shin et al.(2019)의 연구와 비교해 볼 때, /리 음소 출현율은 낮았지만, 그 외 음소는 유사한 분포를 나타내었다. /리 음소의 경우에는 유의미 일 음절의 수 자체가 적기 때문에 실제 자유발화를 분석한 음소 출현율에 비해 본 연구의 초성검사 문항에서 차지하는 비율이 낮았다. 그리고 / 이믐소를 제외하고 같은 연령대인 7 8세 아동의 자유 발화를 분석한 Shin(2005)의 연구와도 비슷한 결과를 보였다. 종성검 사 문항의 종성 분포는 무종성을 제외하고 /ㄴ/ 음소의 비율이 가장 높았고, 그 다음이 /리, / O/, /ㅁㅇㅢ 순으로 나타나 기존 선 행연구 결과와 유사한 분포를 나타내었다. 


\section{Selection of example words}

보기어의 경우 목표어와 최소대립쌍으로 친숙도, 조음 방법 및 조음 위치를 달리하여 3개씩 제작하였으며, 보기어의 난이 도 수준에 따라 쉬운형과 어려운형으로 각각 구성하여 4지선 다형의 폐쇄형 목록을 제작하였다. 이 중 난이도가 쉬운형은 보기어의 조음 방법과 조음 위치가 목표어와 동일하지 않는 경 우이고, 난이도가 어려운형은 보기어의 조음 방법과 조음 위치 가 목표어와 유사한 경우로 보기어의 경우도 되도록 친숙도가 유사한 단어로 배치하여 친숙도에 따른 단어 선택을 배제할 수 있도록 하였다.

\section{Arrangement of target words}

초성검사 문항과 종성검사 문항을 선정한 후, 한 개의 목표어 와 세 개의 보기어 위치를 무작위로 배치하여 목표어가 4개 단 어 중에서 불규칙하게 나타날 수 있도록 하였다. 또한 Kim et al.(2013)이 제시한 일 음절 음소의 주파수를 참고하여 초성검 사 문항과 종성검사 문항의 음소의 주파수 영역이 고르게 분포 되었는지 확인하였다.

\section{Relevances of test items}

검사 문항의 적절성은 크게 비장애 성인을 대상으로 한 예비 검사와 비장애 아동을 대상으로 한 결과 타당도와 내용 타당 도 검증으로 나누어 분석하였다.

\section{Preliminary evaluation}

20대 비장애 성인 10명(남성: 5명, 여성: 5명, 나이: $22.25 \pm$ 1.49 세)을 대상으로 초성검사 문항 127 개, 종성검사 문항 94 개 로 예비 검사를 시행하였다. 정상 청력의 아동 검사와 동일하게 검사 진행을 하여 틀린 문항을 중심으로 난이도를 알아보고, 검사 방법에서 고려할 점을 조사하였다. 검사 결과, 초성검사 문항에 비해 종성검사 문항을 어려워하였고, 쉬운형에 비해 어 려운형에서 어려워하였다. 모든 검사 문항에서 90 100\%의 정 답률을 보였고, 초·종성검사 문항의 쉬운형에서는 모두 $100 \%$ 의 정답률을 보였다. 문항 중 $90 \%$ 이하의 정답률을 보인 단어는 5 개 미만이었다. 검사 후 피검자들에게 틀린 이유를 물어본 결 과, 초성검사 문항은 쉬운형과 어려운형, 종성검사 문항의 쉬운 형은 비교적 난이도가 어렵지 않다고 느꼈으나 종성검사 문항 의 어려운형에서는 혼동이 되는 경우가 있었다고 답하였다. 또 한 검사 진행 속도가 비교적 빠르고 자극 제시 횟수가 1 회로 한 정되어 있어 결과에 영향을 미친 것으로 응답하여 이와 같은 예비 검사 결과를 본 연구에 일부 반영하였다.

\section{Validity of results}

본 연구에서는 검사 문항의 결과 타당도 검증을 위하여 저학 년(1 2학년)의 비장애 아동을 대상으로 검사 문항의 전체 정답 률과 검사 문항의 종류(초성 vs. 종성)와 난이도(쉬운형 vs. 어려 운형) 및 검사 화자(남성 vs. 여성)에 따른 차이를 비교해 보았다.

\section{Participants}

초등학교 1 2학년 아동 23명 중 한글을 모르는 아동 2명과 검사 당시 중이염으로 인하여 순음청력검사상 $0.5,1,2,4 \mathrm{kHz}$ 의 평균 순음청력역치가 경중도 난청으로 확인된 1 명을 제외하 고, $0.5,1,2,4,8 \mathrm{kHz}$ 에서 $20 \mathrm{~dB} \mathrm{HL}$ 을 확인한 비장애 아동 20명(남아: 10명, 여아: 10명, 만 나이: $7.50 \pm 0.51$ 세)을 대상으 로 하였다. 검사에 참여한 아동은 언어의 음소 발달과 음운 발달 이 완성되는 시기인 6세 이상(Kim \& Shin, 2015; Kwon et al., 2011)이며, 한글 폐쇄형으로 글씨를 읽을 수 있는 초등학교 저 학년인 1 2학년으로 선정하였다.

\section{Procedures}

모든 검사는 방음실(배경소음 $35 \mathrm{dBA}$ 이하)에서 실시하였으 며, 이경검사(VIOT video scope, Interacoustics, Eden Prairie, MN, USA) 결과 정상, 고막운동도검사(TympStar clinical middle ear analyzer, Grason-Stadler, Eden Prairie, MN, USA)상 A형으로 정상, 250, 500, 1,000, 2,000, 4,000, 8,000 $\mathrm{Hz}$ 의 주파수에서 순음청력검사(GSI 61 audiometer, GrasonStadler) 결과 $20 \mathrm{~dB}$ HL을 확인할 수 있는 정상 청력의 아동 을 대상으로 하였다. 아동의 쾌적 수준(the most comfortable level), 즉 편안하게 잘 들을 수 있는 강도로 남·여 화자를 통해 육성(live voice)으로 목표어를 1회씩 불러주고 제시된 4지선다 형 목록 중에서 정답을 체크할 수 있도록 하였다. 또한 난청 아 동에게 보기가 없는 조건에서 따라말하기를 할 경우 다양한 조 음의 문제로 정답의 오류가 생길 수 있고 받아쓰기 방법의 경 우 평가 시간이 길 수 있으며, 난청 아동의 쓰기 능력에 따라 신뢰도에 문제가 있을 수 있다(Katz et al., 2009). 그러므로 본 연구에서는 난이도가 높을 수 있지만, 목표어와 보기어가 함께 시각적으로 제시되는 경쟁 상황에서의 폐쇄형 목록을 따라말 하기 방법으로 검사하였다.

초성과 종성검사 문항의 쉬운형과 어려운형의 네 가지 목록 에 대한 검사 순서는 목표어에 대한 학습효과를 줄이기 위하여 문항의 순서를 무작위로 제시하였고, 검사 소요 시간은 각 목 록 검사 후 쉬는 시간을 포함하여 총 1 시간 30 분 2시간 정도였 으며, 모든 검사는 청각 단서만 제시(audition-only)하는 조건 에서 실시하였다. 초성검사 문항의 점수는 초성검사 문항의 정 답 개수를 전체 개수인 127 로 나눈 후 100 을 곱한 백분율(\%) 
로, 종성검사 문항의 점수는 종성검사 문항의 정답 개수를 전 체 개수인 94로 나눈 후 100 을 곱한 백분율(\%)로 나타내었다.

또한 어휘의 맥락적 이해와 단어의 유사성을 최소화하고 음 소적 문제점의 분석에 대한 평가를 위하여 보기가 있는 조건의 폐쇄형 유의미 일 음절 단어를 이용하였다(Katz et al., 2009). 또한 검사 진행 시 초등학교 저학년 아동의 집중력이 검사 결 과에 영향을 미치지 않도록 한 개의 목록을 평가한 후 쉬는 시 간을 충분히 제공한 결과, 총 검사 소요 시간이 약 1 시간 30 분 2 시간 정도로 다소 길어서 추후 검사 방법에 대한 검토도 필요 할 것으로 생각한다.

\section{Data analysis}

검사 문항의 결과 타당도를 살펴보기 위하여 비장애 아동을 대상으로 초성검사 문항 127 개와 종성검사 문항 94 개의 정답 률을 측정하였다. 그리고 검사 문항의 종류, 난이도 및 검사 화 자에 따른 정답률 결과 차이를 독립표본 $t$ 검정(independent $t-$ test)을 통해 유의수준 0.05 미만에서 비교해서 검증하였다. 자 료 분석을 위해 사용한 소프트웨어는 SPSS version 20.0 (IBM Corp., Armonk, NY, USA)이다.

\section{Validity of contents}

제작한 목표어와 보기어, 정상 청력의 아동의 검사 방법 및 결과를 바탕으로 검사 문항에 대한 내용 타당도를 검증하기 위 하여 청각학 전문가 2 명, 언어학 전문가 2 명, 특수교육학 전문 가 1 명 등 여러 분야의 전문가들에게 목표어와 보기어의 타당 성, 평가 절차의 적절성 등에 대한 자문을 의뢰한 후, 토의 및 검증 작업을 진행하였다.

\section{RESULTS}

\section{Results validity of test items}

\section{Comparison of correct answer rates}

초성검사 문항 127 개와 종성검사 문항 94 개로 검사를 진행 한 결과, 초성검사 문항의 쉬운형과 어려운형에 대한 평균 정답 률은 각각 $97.13 \pm 4.73 \%$ 와 $94.06 \pm 5.40 \%$ 인 반면에 종성검사 문항의 쉬운형은 $92.87 \pm 6.34 \%$, 어려운형은 $86.17 \pm 11.02 \%$ 이 었다. 초성검사 문항의 쉬운형은 최소 정답률은 $83.46 \%$, 어려운 형은 $81.89 \%$ 이었고, 종성검사 문항 쉬운형의 최소 정답률은 $77.66 \%$, 어려운형의 최소 정답률은 $65.96 \%$ 이었으며 최대 정답 률은 모든 문항에서 $100 \%$ 이었다. 초성검사 문항은 종성검사 문항에 비해 정답률이 높았고, 초성검사 문항과 종성검사 문항 모두 쉬운형이 어려운형에 비해 정답률이 높았다. 오답률의 경
우 어려운형이 쉬운형보다 높았으며, 쉬운형의 목표어가 정답이 었다고 하더라도 어려운형에서 목표어로 제시될 때 틀리기도 하고, 쉬운형의 목표어를 틀렸다고 하더라도 어려운형에서 목 표어로 제시될 때는 정답을 보이기도 하였다.

초성검사 문항 쉬운형은 $100 \%$ 의 정답률을 보인 단어는 74 개, $95 \%$ 의 정답률을 보인 단어는 39 개, $90 \%$ 의 정답률을 보인 단 어는 11 개, $85 \%$ 와 $80 \%$ 의 정답률을 보인 단어는 각각 2 개와 1 개 였다. 초성검사 문항 어려운형은 $100 \%$ 의 정답률은 51 개, $95 \%$ 는 37 개, $90 \%$ 는 24개, $85 \%$ 는 5개, $80 \%$ 는 4개, $75 \%$ 는 2개, $70 \%$ 이하는 4 개였다. 종성검사 문항 쉬운형은 $100 \%$ 의 정답률을 보 인 단어는 30 개, $95 \%$ 의 정답률을 보인 단어는 33 개, $90 \%$ 의 정 답률은 14 개, $85 \%$ 정답률은 6 개, $80 \%$ 와 $75 \%$ 는 각각 3 개와 4 개, $70 \%$ 이하의 정답률을 보인 단어는 4개였다. 종성검사 문항 어려 운형은 $100 \%$ 의 정답률은 20 개, $95 \%$ 는 16 개, $90 \%$ 는 13 개, $85 \%$ 는 11 개, $80 \%$ 는 14 개, $75 \%$ 는 2개, $70 \%$ 이하는 18 개였다(Table 1).

단어별 정답률을 분석한 결과, 초성검사 문항은 정답률이 $90 \%$ 이상인 단어가 쉬운형에서 124 개, 어려운형에서는 118 개였으 며, $90 \%$ 미만인 단어는 쉬운형에서 "얼, 찍, 옥"의 3개와 어려운 형에서 “북, 옥, 뜸, 끌, 번, 혼, 썩, 운, 찍, 빽, 릴, 반, 빵, 댐, 퍽”의 15 개로 이들 단어는 정답률이 낮은 점수를 나타내어 최종 단 어 선정 시 적합성에 대한 검토가 더 필요할 것으로 생각된다. 종성검사 문항의 94 개 단어 중 정답률이 $90 \%$ 이상인 단어는 쉬운형에서 77 개, 어려운형에서는 49 개였으며, $90 \%$ 미만인 단 어는 쉬운형에서는 “솣, 통, 구, 봉, 논, 거, 박, 겁, 곤, 엿, 토, 고, 홍, 잔, 것, 톤, 격"의 17 개, 어려운형에서는 “논, 건, 응, 석, 역, 톤, 단, 실, 동, 집, 짐, 상, 박, 염, 솔, 각, 통, 홍, 잔, 밭, 무, 것, 군, 함, 본, 방, 겁, 법, 당, 볏, 솣, 낫, 봉, 엿, 격, 중, 담, 밤, 탁, 악, 토, 공, 청, 탑"의 45 개의 단어로 조사되었다.

\section{Differences according to the test type}

검사 문항(초성 vs. 종성)의 종류에 따른 정답률의 차이를 비 교한 결과, 초성검사 문항의 쉬운형과 어려운형 $(t=2.41, p<$

\begin{tabular}{|c|c|c|c|c|}
\hline \multirow{2}{*}{$\begin{array}{c}\text { Correct response } \\
(\%)\end{array}$} & \multicolumn{2}{|c|}{ Initial consonant test } & \multicolumn{2}{|c|}{ Final consonant test } \\
\hline & Easy item & Hard item & Easy item & Hard item \\
\hline 100 & 74 & 51 & 30 & 20 \\
\hline 95 & 39 & 37 & 33 & 16 \\
\hline 90 & 11 & 24 & 14 & 13 \\
\hline 85 & 2 & 5 & 6 & 11 \\
\hline 80 & 1 & 4 & 3 & 14 \\
\hline 75 & - & 2 & 4 & 2 \\
\hline$\leq 70$ & - & 4 & 4 & 18 \\
\hline Total & 127 & 127 & 94 & 94 \\
\hline
\end{tabular}


Table 2. The comparison of the difference in correct response rates according to the type of test items (initial consonant vs. final consonant)

\begin{tabular}{lccc}
\hline & Correct response (\%) & $t$ & $p$ \\
\hline Easy item & & 2.41 & $0.02^{*}$ \\
$\quad$ Initial consonant & $97.13 \pm 4.73$ & & \\
$\quad$ Final consonant & $92.87 \pm 6.34$ & & \\
Hard item & & 2.87 & $0.01^{*}$ \\
$\quad$ Initial consonant & $94.06 \pm 5.40$ & & \\
$\quad$ Final consonant & $86.17 \pm 11.02$ & & \\
\hline
\end{tabular}

Data are presented as mean \pm standard deviation. ${ }^{*} p<0.05$

Table 3. The comparison of the difference in correct response rates according to the difficulty of the test items (easy item vs. hard item)

\begin{tabular}{lccc}
\hline & Correct response (\%) & $t$ & $p$ \\
\hline Initial consonant & & 1.91 & 0.06 \\
$\quad$ Easy item & $97.13 \pm 4.73$ & & \\
$\quad$ Hard item & $94.06 \pm 5.40$ & & \\
Final consonant & & 2.36 & $0.03^{*}$ \\
$\quad$ Easy item & $92.87 \pm 6.34$ & & \\
Hard item & $86.17 \pm 11.02$ & & \\
\hline
\end{tabular}

Data are presented as mean \pm standard deviation. ${ }^{*} p<0.05$

0.05), 종성검사 문항의 쉬운형과 어려운형 $(t=2.87, p<0.05)$ 은 유의수준 0.05 미만에서 각각 통계적으로 유의미한 차이를 보였다(Table 2).

Differences according to the test difficulty

검사 문항의 난이도(쉬운형 vs. 어려운형)에 따른 정답률의 차이를 비교한 결과, 초성검사 문항의 경우 쉬운형과 어려운형 의 목록은 통계적으로 유의미한 차이가 없는 것으로 나타났으 나 $(t=1.91, p>0.05)$, 종성검사 문항은 쉬운형과 어려운형의 목록에 대한 정답률은 통계적으로 유의미한 차이를 보였다 $(t=$ 2.36, $p<0.05$ ) (Table 3).

\section{Differences according to test speakers}

남.여 검사 화자의 성별에 따른 결과 차이를 분석한 결과, 네 가지 목록 모두에서 남성 화자가 검사한 결과보다 여성 화자 가 검사한 결과의 정답률이 높았다. 검사 초성검사 문항 쉬운형 은 유의확률 0.14 , 어려운형은 유의확률 0.15 로 차이가 없는 것 으로 나타났다 $(p>0.05)$. 종성검사 문항 쉬운형과 어려운형도 각각 유의확률 0.42 와 0.24 로 화자의 성별에 따른 차이는 없었 다 $(p>0.05)$ (Table 4).

\section{Content validity of test items}

전문가 집단에 의한 내용 타당도를 검증한 결과, 전체적인 검 사 문항은 학령기 아동용으로 적절하다고 평가하였다. 다만, 검
Table 4. The comparison of the difference in correct response rates according to the test speaker (male vs. female)

\begin{tabular}{clccc}
\hline & Speaker & Correct response (\%) & $t$ & $p$ \\
\hline Initial consonant & & & & \\
Easy item & Male & $95.51 \pm 6.11$ & -1.59 & 0.14 \\
& Female & $98.74 \pm 2.01$ & & \\
Hard item & Male & $92.28 \pm 6.07$ & -1.52 & 0.15 \\
& Female & $95.83 \pm 4.20$ & & \\
Final consonant & & & & \\
Easy item & Male & $91.70 \pm 6.46$ & -0.82 & 0.42 \\
& Female & $94.04 \pm 6.33$ & & \\
Hard item & Male & $83.19 \pm 12.32$ & -1.23 & 0.24 \\
& Female & $89.15 \pm 9.20$ & & \\
\hline
\end{tabular}

Data are presented as mean \pm standard deviation

사 문항의 구성에 있어서 목표어 한 개와 보기어 세 개의 4지선 다형 문항은 전체적인 난이도가 높을 수 있다고 판단하였고, 특히 종성검사 문항의 경우 친숙도가 듣기 능력보다 우선하여 친숙한 단어로 답할 가능성이 있다고 하였다.

\section{DISCUSSIONS}

본 연구는 비장애 아동을 대상으로 초성과 종성의 음소지각 능력을 평가할 수 있는 폐쇄형 유의미 일 음절 초성검사 문항 과 종성검사 문항의 타당도와 난이도를 검증하여 학령기 아동 용 음소지각검사 도구 개발 및 보급을 위한 기초 자료로 활용 하고자 하였다.

제작한 학령기 아동용 음소지각검사 도구의 적절성 검증을 위하여 비장애 아동 20 명을 대상으로 결과 타당도를 검증하였 다. 연구 결과, 검사 문항의 정답률 비교에서 종성검사 문항의 정답률이 초성검사 문항보다 낮게 나타나 초성검사 문항보다 전반적으로 난이도가 높음을 알 수 있었다. 또한 검사 문항의 난이도(쉬운형 vs. 어려운형) 측면에서는 초성검사 문항과 종성 검사 문항 모두 쉬운형에 비해 어려운형의 정답률이 더 낮게 나타나 초·종성검사 문항의 난이도 배치가 적절함을 알 수 있 었다. 또한 이 연구에 참여한 아동은 청력검사를 통해 정상 청 력임을 확인했으나, 아동의 읽기 능력이나 음운 인식과 같은 구 체적인 언어적인 평가를 시행하지 않은 상태에서 음소지각검사 를 진행하여 단어의 정답률에도 어느 정도는 영향을 미쳤을 것 으로 생각한다.

검사 문항에 대한 하위 범주별 정답률 차이를 비교한 결과, 검사 문항의 난이도 비교에서는 종성검사 문항의 경우 쉬운형 의 정답률이 어려운형보다 약 $6.7 \%$ 정도 높게 나타나 통계적으 로 유의미하게 차이를 보였으나, 초성검사 문항의 경우에는 그 
차이가 유의미하게 나타나지 않았다 $(p>0.05)$. 즉, 초성검사 문항은 어려운형인데도 불구하고 정답률이 쉬운형과 큰 차이 가 없었고, 종성검사 문항의 쉬운형에 비해서도 높게 나타나 추 후 초성검사 문항의 어려운형에 대한 난이도의 재검토가 필요 할 것으로 생각한다. 검사 화자에 따른 차이 비교에서 모든 검 사 문항에서 여성 화자의 정답률이 남성 화자의 정답률에 비해 높았으나, 화자 간 차이는 통계적으로 유의미한 차이를 보이지 않아 $(p>0.05)$, 검사 화자의 성별에 따라 검사 결과에 영향을 미치지 않았음을 시사한다. 다만 이번 연구에서는 녹음된 음원 으로 진행한 검사가 아니었기 때문에 성별에 의한 차이 외에도 개개인의 발음, 검사 속도 등의 개별 화자에 따른 요인이 작용하 여 어느 정도 영향을 미쳤을 것으로 판단되므로 추후 동일한 성 별의 여러 명의 화자를 대상으로 한 비교 연구를 추가적으로 진 행한다면, 더 정확한 결과를 도출할 수 있을 것으로 생각한다.

전문가 집단을 대상으로 한 내용 타당도 검증에서는 전체적 인 검사 문항은 학령기 아동용으로 적절하다고 평가하였다. 다 만, 글자로 제시될 경우 특히 종성검사 문항은 친숙도가 듣기 능력보다 우선하여 친숙한 단어로 답할 가능성이 있다고 하였 다. 본 연구를 통해 살펴본 종성검사 문항은 목표어가 보기어보 다 피검자에게 노출이 적은 단어가 많이 배치된 경우가 있어 검 사 진행 시 제시된 목표어를 선택하기보다는 보기어를 선택할 가능성이 높을 수 있다고 하였다. 또한 단어의 선다형을 제시한 외국의 폐쇄형 검사 도구는 음소 분리를 잘할 수 있으나 쓰기, 읽기와 철자를 어려워하는 환자에게는 사용하기 적합하지 않 았다고 하였다(Houset et al., 1965; Owens \& Schubert, 1977). 그러므로 추후 음소지각검사 도구를 최종 제작할 때 문항 수를 늘리거나 보기어 선정 시 조음 방법, 위치뿐만 아니라 유사 주 파수 음소 분석 등을 통해서 전체적인 검사 문항에 대한 난이 도를 조절할 필요가 있고, 특히 종성검사 문항의 경우 친숙도가 높은 목표어를 더 배치하는 것이 바람직할 것으로 생각한다. 또 한 초성검사 문항 중 $/ 0 /$ 음소를 포함한 목표어가 중성·종성 의 배치로 인해서 초성검사라고 명명하기에는 다소 제한점이 있고, 종성검사 문항 중 종성이 없는 무종성의 목표어 역시 초 성·중성 배치로 인하여 종성검사라고 하기에 음소지각검사의 본질에 있어 논의의 대상이 될 수 있다. 하지만 공식적인 아동 용 음소지각평가로 사용되고 있는 기존 유의미 일 음절 검사 도구들의 경우에도 초성의 / $/ 0$ 음소와 무종성을 포함한 일 음 절로 구성되어 있으므로 추후 이에 대한 정확한 정의가 필요할 것으로 생각된다(Kim et al., 2008; Lee et al., 2009).

본 연구를 통해서 학령기 아동의 음소지각 능력을 검사할 수 있는 학령기용 검사 문항을 분석한 결과, 초성검사 문항 127 개 중 쉬운형 124 개, 어려운형 117 개와 종성검사 문항 94 개 중 쉬 운형 77 개, 어려운형 49 개는 정답률이 $90 \%$ 이상인 것으로 검
증되었다. 후속 연구에서는 정답률 $90 \%$ 이상인 검사 문항 중 에서 목표어의 개수를 줄이고, 본 연구 결과에서 나타난 검사 방법상의 문제점을 보완할 필요가 있다. 특히 아동의 집중력 저하를 방지하여 정확한 결과를 도출하기 위해서 초성검사 문 항과 종성검사 문항의 쉬운형을 함께 검사하고, 초성검사 문항 과 종성검사 문항의 어려운형을 함께 검사하는 등 다양한 검사 방 법에 대한 고찰을 통해서 한 목록당 검사 소요 시간이 15 20분 이내가 될 수 있도록 조절하는 것도 고려해야 할 것이다. 또한 학령기용 음소지각검사 도구 개발을 위한 검증 자료로 일반화 하기에는 연구 대상의 수가 부족하므로 더 많은 비장애 아동 에 대한 검증과 더불어 난청 아동을 대상으로 한 연구를 진행 한다면, 학령기 아동을 위한 음소지각검사 도구 개발에 많은 기여를 할 수 있을 것으로 생각한다. 그리고 추후 개발될 학령 기용 음소지각검사 도구를 통하여 자음의 오류 패턴을 확인하 고 난이도별 이형검사 목록을 통해서 청능재활 전·후의 중재 효과를 평가할 수 있으며, 보청기 조절 및 적합 등의 청능재활 과정에서 유용하게 사용할 수 있을 것으로 기대한다.

중심 단어 : 청능재활·폐쇄형·학령기용 음소지각검사·학령기 아동·말지각.

\section{Ethical Statement}

The study was approved by the Institutional Review Board of Sehan University (SH-IRB 2018-02).

\section{Acknowledgments}

Thanks to research assistances, Heo, J. W., Jung, H. J., Park, E. Y., Kim, S. Y., and participants.

\section{Declaration of Conflicting Interests}

There are no conflict of interests.

\section{Funding}

This work was supported by the Ministry of Education of the Republic of Korea and the National Research Foundation of Korea (NRF-2017S1 A5A8020193).

\section{Author Contributions}

Conceptualization: Eun-Yeong Shin. Data curation: all authors. Formal analysis: all authors. Funding acquisition: Eun-Yeong Shin. Investigation: all authors. Methodology: all authors. Writing_original draft: Eun-Yeong Shin, Soo Jin Cho. Writing_review \& editing: HyoIn Lee. Approval of final manuscript: all authors.

\section{ORCID iDs}

Eun-Yeong Shin https://orcid.org/0000-0002-7464-1420

Soo Jin Cho https://orcid.org/0000-0003-1752-5172

\section{REFERENCES}

Allum-Mecklenburg, D. J., Allum, J. H. J., Baumgartner, W., Bieri, T., \& Esser, B., et al. (1996). Multilanguage international perceptual test battery for comparing performance of children in different countries: evaluation of auditory responses to speech (EARS). Proceedings of the 
3rd European Symposium on Pediatric Cochlear Implantation, Hannover, Germany.

Archbold, S., Lutman, M. E., \& Marshall, D. H. (1995). Categories of Auditory Performance. The Annals of Otology, Rhinology and Laryngology. Supplement, 166, 312-314.

Bahng, J., Lee, J., Hong, B. N., \& Kim, J. (2005). A study on the development of word recognition test by pictures. Korean Journal of Audiology, 9(2), 133-142.

Erber, N. P. (1982). Auditory training. (pp. 29-45). Washington, DC: Alexander Graham Bell Association for the Deaf.

Geers, A. E., Nicholas, J., Tye-Murray, N., Uchanski, R., Brenner, C., Davidson, L. S., et al. (2000). Effects of communication mode on skills of long-term cochlear implant users. The Annals of Otology, Rhinology and Laryngology. Supplement, 185, 89-92.

Griffiths, J. D. (1967). Rhyming minimal contrasts: a simplified diagnostic articulation test. The Journal of the Acoustical Society of America, 42(1), 236-241.

House, A. S., Williams, C. E., Heker, M. H., \& Kryter, K. D. (1965). Articulation-testing methods: consonantal differentiation with a closed-response set. The Journal of the Acoustical Society of America, 37(1), 158166.

Katz, J., Medwetsky, L., Burkard, R., \& Hood, L. (2009). Handbook of Clinical Audiology. (6th ed.). Baltimore, MD: Lippincott Williams \& Wilkins.

Kim, G. H. (2003). Vocabulary for Korean Language Education by Grade. Seoul: Pagijong Press.

Kim, J. S., Lim, D., Hong, H. N., Shin, H. W., Lee, K. D., Hong, B. N., et al. (2008). Development of Korean standard monosyllabic word lists for school aged children (KS-MWL-S) and preschoolers (KS-MWL-P). Audiology and Speech Research, 4(2), 141-160.

Kim, J. S., Shin, E. Y., \& Cho, E. B. (2013). A Study on Initial · Middle · Final Phoneme Frequency Analyses of the Korean Meaningful Monosyllabic Words. Audiology and Speech Research, 9(2), 127-136.

Kim, J. S., Shin, E. Y., Shin, H. W., \& Lee, K. D. (2011). Development of Korean consonant perception test. The Journal of the Acoustical Society of Korea, 30(5), 295-302.

Kim, L. S., Lee, M. Y., Huh, M. J., \& Oh, Y. J. (2004). Open-set speech preception development in children with cochlear implants. Korean Journal of Otolaryngology-Head and Neck Surgery, 47(1), 15-21.

Kim, S. J. \& Shin, J. Y. (2015). Speech Sound Disorders. Seoul: Sigmapress. Kirk, K. I., Pisoni, D. B., \& Osberger, M. J. (1995). Lexical effects on spoken word recognition by pediatric cochlear implant users. Ear and Hearing, 16(5), 470-481.

Kwon, D. H., Lee, M. S., Shin, H. N., Shin, H. J., Jeong, B. S., Jeon, H. S., et al. (2011). Language Development. Seoul: Pakhaksa.

Lee, J. H. (2014). [Lectures on Korean Phonology]. (2nd ed). Seoul: Samkyung munwhasa.

Lee, M. Y., Shin, J. C., Kim, H. H., \& Kim, L. S. (2009). Open-set monosyllabic speech perception test for preschool children. Korean Journal of Otorhinolaryngology-Head and Neck Surgery, 52(4), 312-321.

National Institute of the Korean Language. (2003). Vocabulary List for Learning Korean. Seoul: The National Institute of the Korean Language.

Northern, J. L. \& Downs, M. P. (2002). Hearing in Children. (5th ed.). (pp. 2-31). Baltimore, MD: Lippincott Williams \& Wilkins.

Owens, E. \& Schubert, E. D. (1977). Development of the California Consonant Test. Journal of Speech and Hearing Research, 20(3), 463-474.

Park, M. H., Lee, K. S., Huh, M. J., \& Lee, S. H. (2004). Early development of auditory performance in implanted infants and children with EARS-K in Korea. Cochlear Implants International, 5 Suppl 1, 120-124.

Pederson, O. T. \& Studebaker, G. A. (1972). A new minimal contrasts closed-response-set speech test. Journal of Audiological Research, 12, 187-195.

Shin, E. Y., Shin, S. K., \& Cho, S. J. (2019). Analysis of appearance frequency of phonemes for daily life speech sounds of 6 to 8 year old children. Journal of Learner-Centered Curriculum and Instruction, 19(3), 387-409.

Shin, J. Y. (2005). Phoneme frequency of 3 to 8 -year-old Korean children. Korean Linguistics, 27, 163-199.

Song, Y. J., Lee, H. J., \& Jang, H. S. (2010). A Study on the Development of KNISE-DASP (KNISE-Developmental Assessment of Speech Perception) for Auditory Training. Asan: National Institute of Special Education.

The Korean Audiological Society. (2015). Speech Perception Test in Practice. Seoul: Hakjisa.

Tye-Murray, N. (2015). Foundation of Aural Rehabilitation Children, Adults, and Their Family Members. (4th ed.). San Diego, CA: Delmar Cengage Learning.

Wang, N. Y., Eisenberg, L. S., Johnson, K. C., Fink, N. E., Tobey, E. A., Quittner, A. L., et al. (2008). Tracking development of speech recognition: longitudinal data from hierarchical assessments in the Childhood Development after Cochlear Implantation Study. Otology and Neurotology, 29(2), 240-245. 